\title{
Chapter 12 \\ Research on Ukrainian Migration to Spain: Moving Beyond the Exploratory Approach
}

\author{
Mikołaj Stanek, Renáta Hosnedlová, and Elisa Brey
}

\subsection{Introduction}

In the first decade of the twenty-first century Spain became an important destination for labour migration. According to official municipal register statistics, between 2000 and 2014 the total number of registered foreign-born persons grew almost fivefold, rising from $1,472,000$ to $6,283,712$. The intensification of immigration was accompanied by a considerable diversification of the origins of immigrants, with immigration from Central and Eastern Europe supplementing earlier migrations into Spain from the Maghreb and Latin America (Arango 2004). Migration from Central and Eastern European countries has grown exponentially over the last fifteen years. According to national population censuses, in 2001 residents from Central and Eastern Europe represented approximately $7 \%$ of the foreign-born population, rising to $24 \%$ by 2011 . This increase in the proportion of migrants from former socialist states was due mainly to the arrival on a massive scale of Romanian and Bulgarian migrants and, though to a lesser extent, Ukrainian migrants (Marcu 2007; Stanek 2009). Ukrainians currently constitute the third-largest community among migrants from Central and Eastern Europe residing in Spain.

The increase of the population coming from Central and Eastern European countries to Spain has awoken substantial interest within the Spanish academic commu-

\footnotetext{
The original version of this chapter was revised. An erratum to this chapter can be found at DOI 10.1007/978-3-319-41776-9_14

M. Stanek $(\bowtie)$

Department of Sociology and Communication, University of Salamanca, Salamanca, Spain e-mail: mstanek@ces.uc.pt

R. Hosnedlová

LabEx SMS, The Federal University of Toulouse, Midi-Pyrénées, France

E. Brey

GEMI, Complutense University of Madrid, Madrid, Spain
} 
nity, which is reflected in the growing number of publications (see, among others, Hellerman and Stanek 2006; Marcu 2007; Viruela Martínez 2002). Although a great deal of the work focuses on Romanian migrants in Spain, Ukrainian migration has been receiving increasing attention from Spanish researchers over the last decade and a half. This chapter argues that, while the efforts of several researchers have undoubtedly contributed to a better understanding of current Ukrainian migration, Spanish migration research on this population still faces several challenges. Its objective is threefold: first, to assess key data sources on Ukrainians in Spain; second, critically to review current literature on this collective and assess existing conceptual and empirical tools applied in the research; and third, to discuss the value of the knowledge acquired, and highlight future challenges.

The chapter is structured as follows. Section 12.2 provides a critical overview of the key data sources for the measurement of Ukrainian migration and population. Several indicators used for describing main social and demographic features of the Ukrainian population residing in Spain are discussed. Section 12.3 consists of a critical literature survey about processes of social and cultural integration of Ukrainians. In Sect. 12.4 results of recent studies on patterns of international mobility of Ukrainians and transnational behaviour are discussed. Conclusions are drawn in Sect. 12.5. Data and literature discussed in the previous sections are used to assess the extent to which Spanish studies of Ukrainian migration have managed to explore and explain its most prominent features. Issues and topics related to this migration that require further research are also identified.

\subsection{Socio-demographics of Ukrainians in Spain}

This section gives the main statistical data sources used to describe the Ukrainian population in Spain. The ability of each source to provide comprehensive and reliable measures of flows, stocks and socio-demographic structure of this collective is assessed. The advantages and limitations of statistical data are highlighted, and the main socio-demographic features of Ukrainian migration are presented.

\subsubsection{Main Data Sources on Ukrainian Migration in Spain}

By the turn of the century, the substantial improvement in the quality and coverage of the municipal registries had made their statistical data the principal source of information on inflow, stock and basic socio-demographic composition of the foreign population in Spain (see González-Ferrer 2009). Since it includes foreigners residing in Spain regardless of their legal status (Rosero-Bixby et al. 2011), it is a more reliable source of information on this population than residence permit statistics provided by the Ministry of Labour and Social Security. It is assumed that the coverage of municipal population registers in the period 2001-2012 is high, since registration provides automatic access to health services and education even for 
those who do not have a legal residence permit upon arrival. Municipal registers not only provide information regarding volume of population by country of birth and nationality but also basic socio-demographic features such as sex, age, region and province of residence in Spain.

However, several authors have suggested that municipal register statistics are not fully accurate as they tend to underestimate some categories of migrants (e.g., foreign-born pre-school children, seasonal workers) (González-Ferrer 2009). On the other hand, it has also been highlighted that the total stock of foreigners is mainly overestimated due to double registration (Ródenas-Calatayud and Martí 2009; Rosero-Bixby et al. 2011). Finally, it may be assumed that the restrictions on access to Spain's free health-care system imposed by the Spanish government on undocumented migrants between 2012 and 2015 has undermined incentives to register voluntarily among this category of foreign population which, in turn, affects the accuracy of municipal registers.

Residential Variation Statistics (EVR) derived from municipal registers show entries and removals produced due to residence changes and are also used to estimate inflow and outflow of the foreign population. In recent years they have become an important source for the exploration of this phenomenon (Larramona 2013; Parella and Petroff 2014). Although increasingly used, this source is not without its flaws. First, the EVR does not include complete information on the destination of the outbound flows since individuals are not obliged to provide that information when deregistering. Second, a significant number of deletions from the municipal register are due to immigrants failing to renew their residency. Consequently, there is a significant delay between the actual departure of the individual and the deletion of their entry from the register. Third, there are hardly any incentives for people from Spain moving abroad to deregister as they lose access to some state welfare benefits and there are no administrative sanctions for remaining on the register, so outflow figures might be underestimated. Finally, it should be noted that the EVR counts movements and not persons moving. So it is possible for the same person to register and deregister several times over the course of a year, each of which would be counted as a different movement.

Several studies on socio-demographic features of Ukrainian immigrants published in recent years have taken advantage of the National Immigrant Survey data set (NIS-2007) obtained by the Spanish National Institute of Statistics at the start of 2007. This survey was based on a sample of 15,465 people which included foreignborn persons over 15 years old who had been in Spain for at least 1 year at the time of the interview. To ensure maximum representativeness NIS-2007 followed a complex three-stage sampling design to select dwellings in which at least one resident was a foreign national (see Duque et al. 2014). The survey includes detailed information on personal characteristics (such as gender, age, education level, country of origin, year of arrival, marital status and region of origin) and traces occupational and residential trajectories in Spain and previous migration experience. The survey also looks into collective aspects of migration with questions on immigrants' family structure and geographical location of their members, household composition and relations with the country of origin (Reher and Requena 2009). Hosnedlová and Stanek (2010a, b) made extensive use of this database in their research on the 
socio-demographic profiles of Ukrainian migrants. These authors also relied on NIS-2007 in their exploration of Ukrainian migrants' patterns of transnational behaviour (see Stanek and Hosnedlová 2012; Hosnedlová and Stanek 2014). The results of this research will be assessed in following sections of this chapter.

Although NIS-2007 was an exceptional data set in the European context which shed new light on several aspects of the immigration phenomenon in Spain, its shortcomings mean the results of the analysis of the Ukrainian case should be interpreted with caution. First, the subsample of Ukrainian migrants is relatively small (223 individuals) which to some extent affects the accuracy and validity of the results, so robust and more effective methods of statistical analysis are required to avoid small-sample bias and to yield finite and consistent estimates (see Stanek and Hosnedlová 2012). Second, NIS-2007 does not cover areas of interest such as measurement of the costs associated with international mobility and several issues related to integration processes (see González-Ferrer 2009; Duque et al. 2014). Finally, NIS-2007 was produced when the economic situation in Spain was still favourable. The outbreak of the economic crisis significantly altered the situation of immigrants in Spain. NIS-2007 outcomes should therefore be interpreted taking into account the specific socio-economic conditions of the period when its data were collected.

The fourth most important source of statistical data regarding Ukrainian immigration available in Spain is the population census. The advantages of census data for exploring features of foreign collectives are well known. They provide very reliable measures of the volume of foreign population and include a wide set of socioeconomic and socio-demographic variables (such as age, gender, occupation, education level, year of arrival) which enable the main features of immigrant collectives to be explored. The census is especially valuable for its considerable data regarding household structure and family members' characteristics. On the other hand, the limitations of census data are also well known. As it is designed to gather basic information on the whole population, the number of variables regarding specific features of immigrant collectives is limited. In addition, the decennial temporal gaps between censuses make it difficult to fully understand the population trends. Despite these limitations the latest census (2011) provides currently the most up-to-date statistical information on specific features of Ukrainian migrants that are not included in municipal registers: educational level, labour market situation and living conditions.

\subsubsection{Dynamics of Ukrainian Migration Flows and Evolution of Socio-demographic Features}

What is the dynamic and volume of Ukrainian migration, according to statistical data? The first Ukrainian economic migrants arrived in Spain in the mid-1990s. Although we lack reliable statistical data for this period, it can be assumed that the influx was relatively large. After the regularization processes of 2000 and 2001 Spanish statistics displayed a sharp increase in immigrants of this origin. Between 


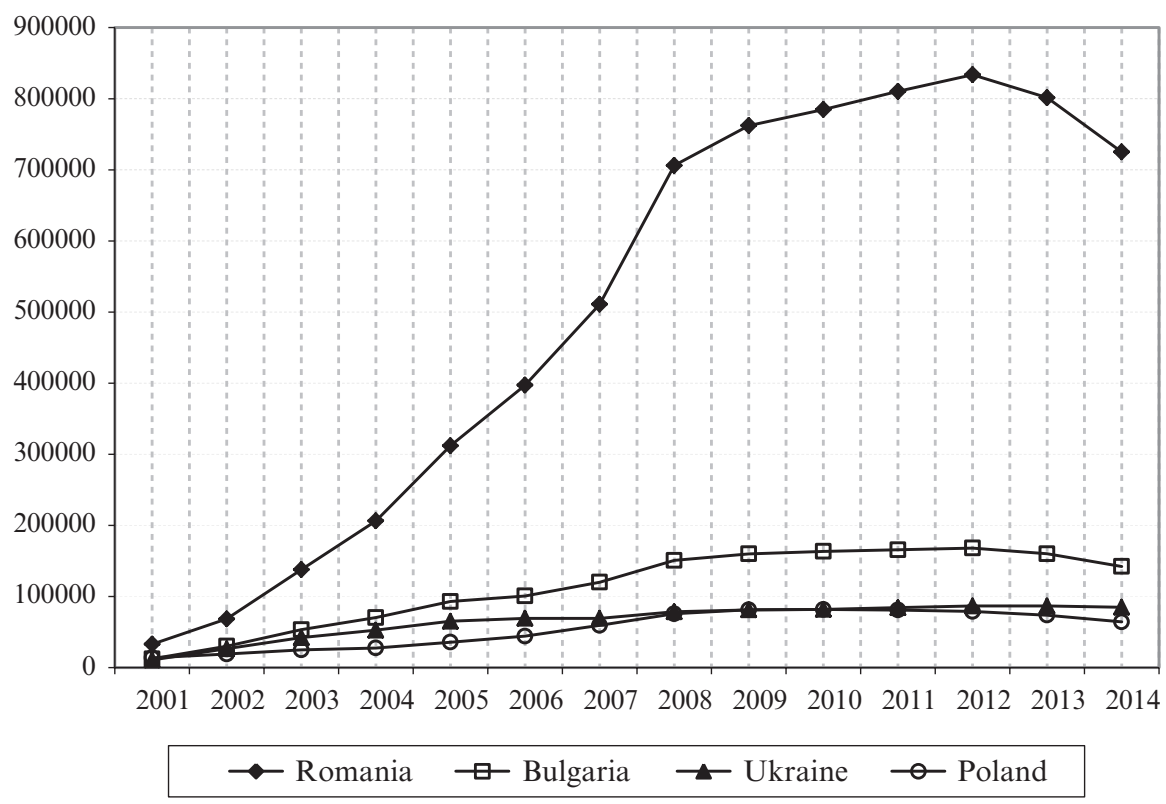

Fig. 12.1 Major immigrant groups from Central and Eastern Europe in Spain, 2001-2014 (Source: Authors' own compilation based on data from the Municipal Register 2001-2014, National Institute of Statistics (Spain))

1996 and 2001 the number of Ukrainians with residence permits grew from 240 to approximately 9,500 (Ferrero Turrión 2005). By 2001 approximately 25,500 Ukrainians were registered in Spanish municipalities. In the years that followed, the number of Ukrainians registered in municipal registers increased exponentially, reaching 81,132 by 2009. In recent years the migration of Ukrainians to Spain has slowed down as a result of the economic downturn and the corresponding dramatic increase in unemployment and budget cuts. At the beginning of 2014, the total number of Ukraine-born migrants registered in Spain was approximately 85,000. For the purposes of comparison, data is included on Romanian, Bulgarian and Polish migrants who, together with Ukrainians, constitute the largest groups among the Central and Eastern European residents in Spain. Figure 12.1 shows the contrast between the stagnation in numbers of Ukrainians and the significant decrease in numbers of other major Central and Eastern European migrant groups.

The analysis of Residential Variation Statistics which draw on municipal register data and reflect movements between municipalities and regions, as well as departures abroad, can help to shed some light on observed differences. As can be seen in Figs. 12.2-12.5, since the economic crisis started in 2007, the entry of new migrants to Spain has decreased considerably when all four countries are taken into account. However, in the case of migrants from Romania, Bulgaria and Poland this decreasing trend coincides with a growing number of departures from Spain. By contrast, net migration seems to be more balanced in the case of Ukrainians. Although since 

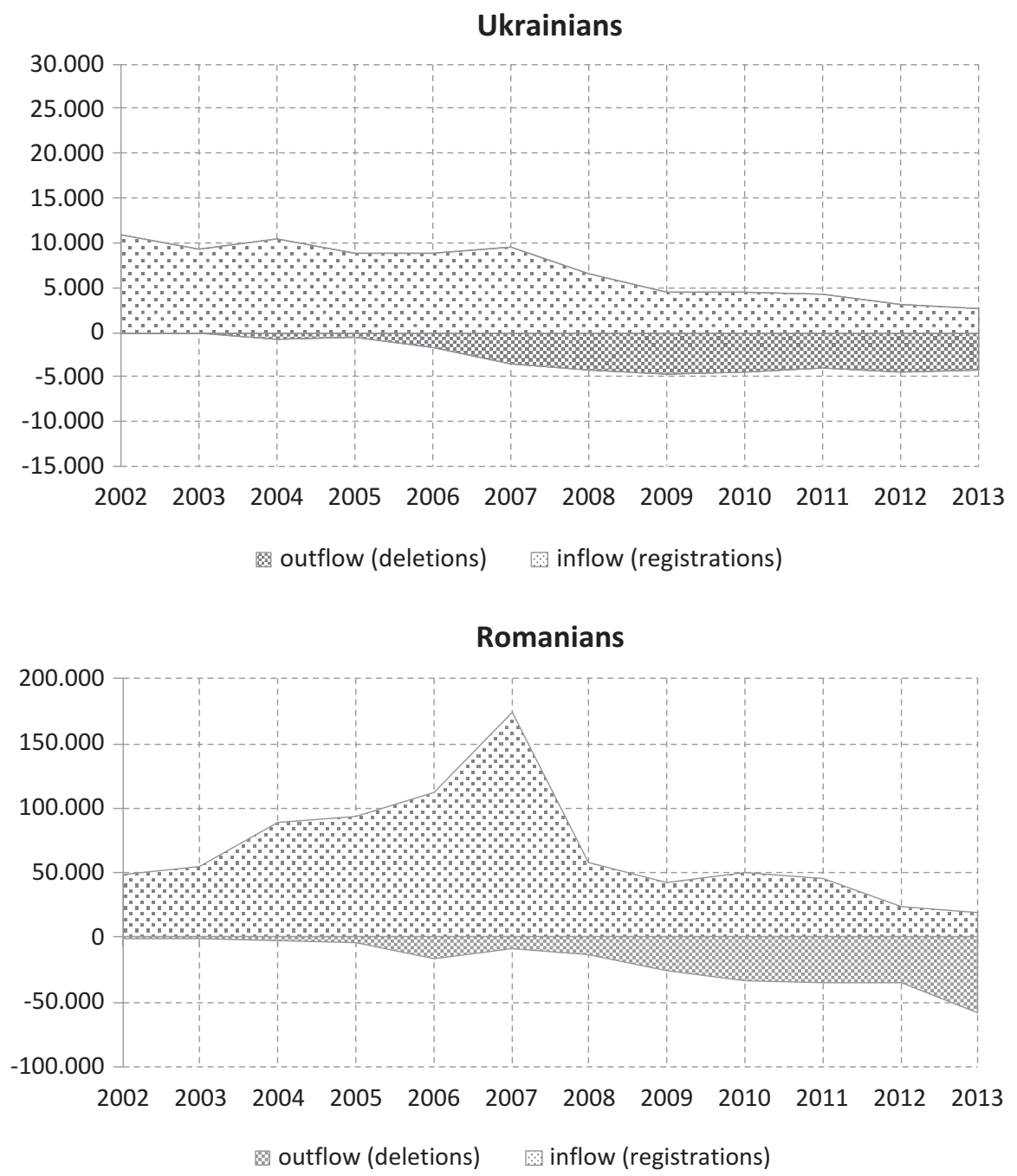

Figs. 12.2-12.5 Outflows and inflows of selected origins (Source: Authors' own elaboration based on deletions and registrations in the Municipal Register 2002-2013, National Institute of Statistics (Spain))

2007 deletions from the municipal register have been increasing, the volume of exits is still smaller compared to other Central and Eastern European countries. On the other hand, in contrast to the other three countries included in this comparison, the number of Ukrainian de-registrations only slightly exceeds the number of new arrivals registered in municipal registers. This seems to be related to the fact that Ukraine is the only one of these four countries that is not a member of the EU and 

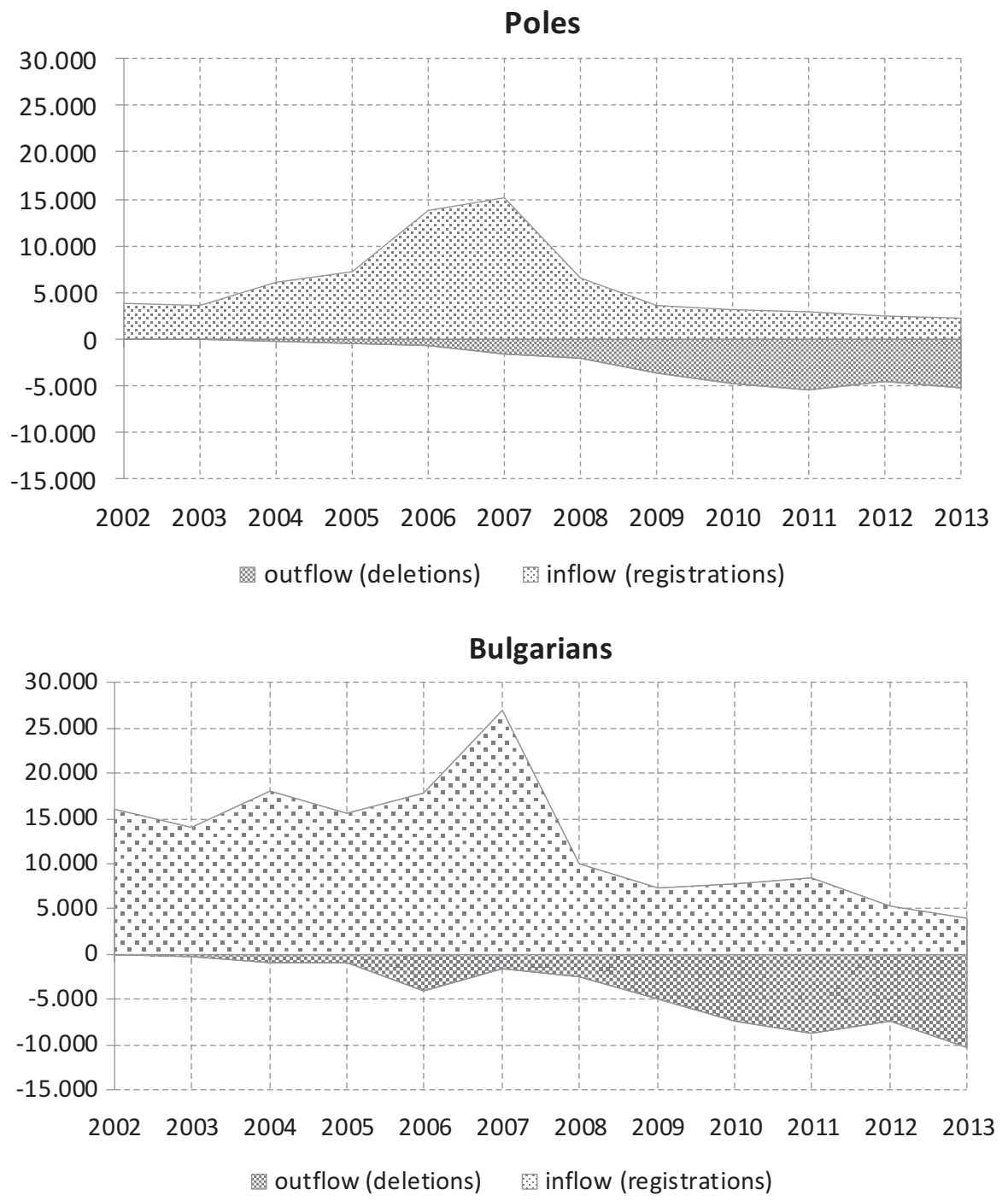

Figs. 12.2-12.5 (continued)

whose citizens' mobility is limited by visa restrictions. For more on the impact of visa regulations on Ukrainian migrants in the EU, see Chap. 4.

The Ukrainian population in Spain has undergone a profound demographic transformation in the last fourteen years. There have been changes in terms of gender (from male dominated to female dominated). More specifically, municipal register statistics indicate that in 2001 this ratio of this immigrant group in Spain was 110 males per 100 females, but in 2014 the ratio was only 75-100. The age distribution has also changed from a clear concentration of immigrants in the economically 


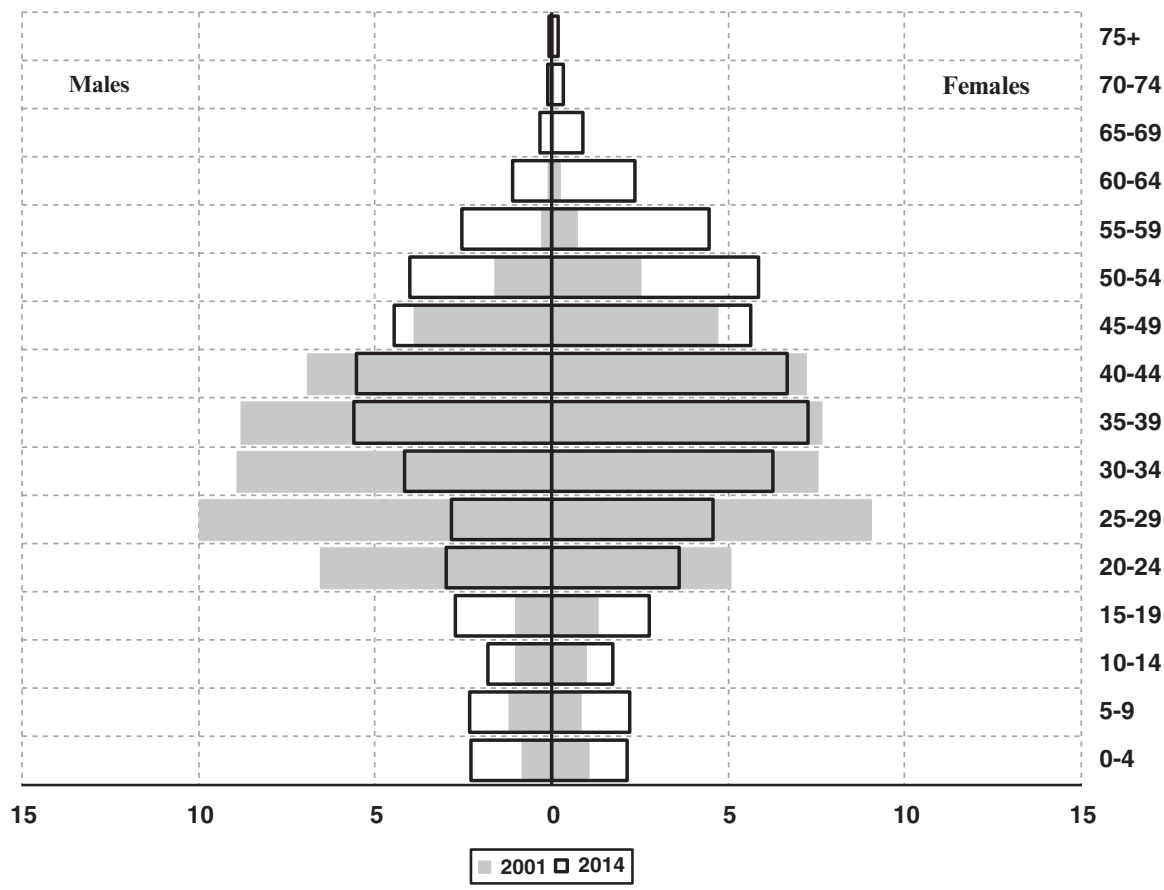

Fig. 12.6 Age-gender distribution of the Ukrainian immigrant population in Spain, 2001 and 2014 (\%) (Source: Authors' own compilation based on data from the Municipal Register (2001 and 2014), National Institute of Statistics (Spain))

productive age groups to a widening of age groups to include children and adults over 44. According to the 2014 data, most of the population falls within the 30-49 age group. The balance between the sexes is of particular interest in the 35-49 age group. Women are in the majority in the 30-34 age group, and especially in the group aged over 50 (see Fig. 12.6). The trends in respect of gender and age seem to indicate that over the past decade the migratory process was initially dominated by men, but this was subsequently compensated by the arrival of women as part of the process of family reunification and due to individual migratory decisions (Hosnedlová and Stanek 2014). The relative increase in the female population in these categories is also due to the fact that Ukrainian males are, as we shall see, over-represented in activities that were hardest hit by the economic crisis, such as construction, and this is reflected in the gender balance of newly arrived Ukrainian migrants. The higher rates of unemployment among Ukrainian men also affect their higher propensity to return or re-emigrate.

Data from the population census of 2001 and National Immigrant Survey 2007 show that the educational structure of the Ukrainian immigrant population in Spain has also undergone an interesting transformation in the last decade. The level of this population's education has been increasing over the years. In 2001 the immigrants were mainly skilled workers or had less than secondary education. Between 2001 and 2007 the majority of new arrivals were people with secondary or tertiary educa- 


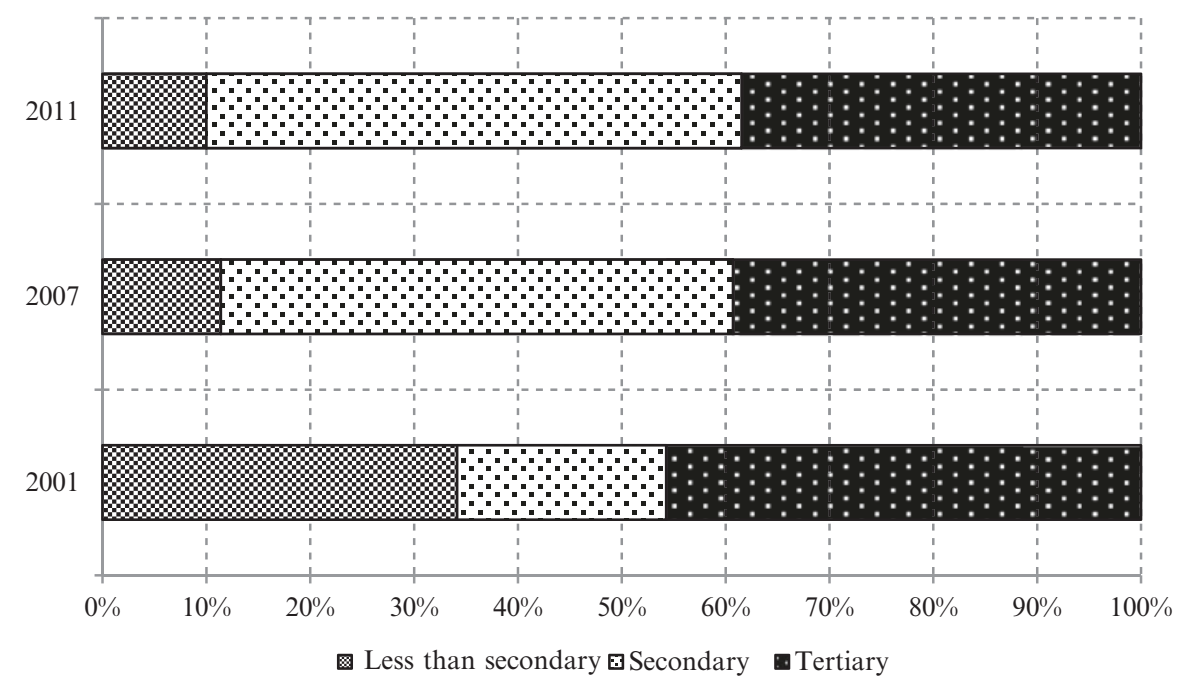

Fig. 12.7 Highest education level achieved by Ukrainian migrants, 2001, 2007 and 2011 (Source: Authors' own compilation based on data from the Populations Censuses (2001 and 2011) and National Immigrant Survey NIS-2007)

tion. According to the National Immigrant Survey, in 2007, 52\% of the Ukrainians in Spain had finished secondary education and 39\% had finished post-secondary education. With the economic crisis, the increase in migrants with secondary and tertiary education stopped. No significant differences appear between the educational structure of the Ukrainian migrant population in 2007 and 2011. According to the census of 2011, approximately $51 \%$ of Ukrainians had a secondary diploma and $38 \%$ had completed tertiary education (see Fig. 12.7). Despite some differences in the data measurement procedure as well as the limitations of National Immigrant Survey data, it can be stated that the deteriorating economic situation has had a considerable impact on the arrival of migrants with the highest level of skills.

\subsubsection{Spatial Dynamics: Regions of Origin and Destination}

According to the municipal registers, in 2014 most Ukrainian immigrants were concentrated in four particular regions: the Madrid region (22\%), Catalonia $(20.1 \%)$, the Valencia region (18.2\%) and Andalusia (15\%). There are also relatively large contingents of Ukrainian immigrants who have settled in other regions of the Mediterranean coast, such as Murcia (Hosnedlová and Stanek 2010a; Sánchez Urios 2010). Map 12.1 shows the internal residential mobility of Ukrainians, revealing which destinations are transitory, which are more prone to permanent settlement and why. According to this visual analysis Madrid is the place with not only the highest concentration of the Ukrainian population, but also with the greatest intermunicipal mobility. In 2007 the region was both an important gateway to the rest of 


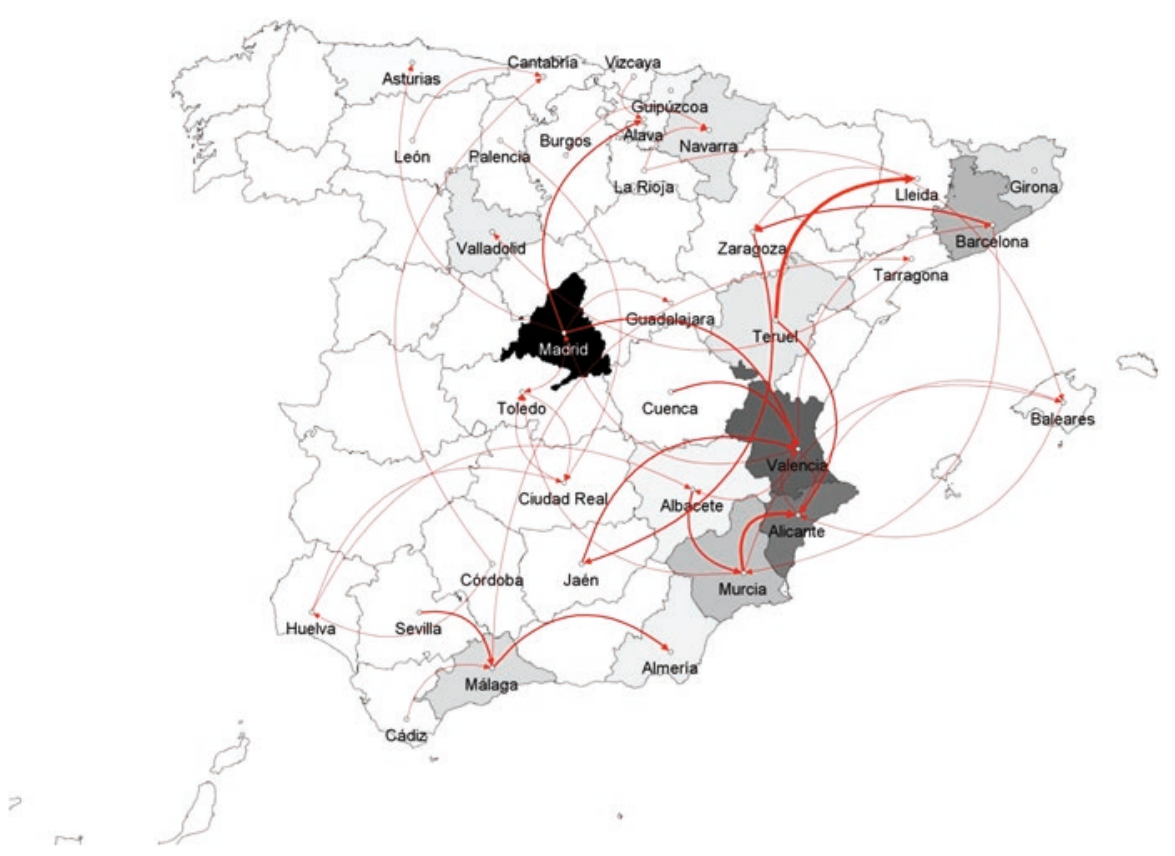

Map 12.1 The inter- and intra-provincial residential mobility of Ukrainians in Spain (from their arrival until the time of the interview) (Source: Own elaboration of Hosnedlová (2014) based on the NIS-2007 data (the weighted data were used)). Note: A scale of proportions has been used in order to represent the volume of flows between provinces (thickness of arrows) and volume of intra-provincial mobility (the darker the tone of the province, the higher inter-municipal mobility). The data comprise only the mobile population $(\mathrm{N}=86)$ and intra-city movements have not been included. The map shows places where the individual has stayed for at least a month, excluding those on holiday

Spain (with its busy international airport and bus routes between Madrid and different Ukrainian cities), and a transit area. However, Madrid does not appear among the most important regions in respect of inter-provincial mobility, nor does it seem to attract a mass of new immigrants from other areas of Spain. This internal mobility seems to be associated with Spanish labour market characteristics. Madrid and Catalonia have attracted Ukrainian immigrants by offering employment in industry (especially women), in construction (men) and in hotels and catering. Valencia, Andalusia and Murcia can offer a wide range of temporary jobs in hotels and catering, agriculture, retail and wholesale trade (Hosnedlová 2014). For a comparison with the spatial concentration of Ukrainian migrants in Poland, see Chap. 7.

As to Ukrainian immigrants' places of origin, according to the results of the National Immigrant Survey, by 2007 over half of the Ukrainian immigrant population came from four provinces located in the western part of the country: Lviv (23.4\%), Ternopil (12.7\%), Ivano-Frankivsk (9.5\%) and Chernivtsi (7.8\%). Many immigrants also came from Kiev province (14.3\%). This pattern is consistent with the results of studies conducted in other Southern European countries which also highlighted a large predominance of immigrants from Western Ukraine in Portugal, Italy and Greece (see Fonseca et al. 2014; Vianello 2014; Nikolova 2015). 


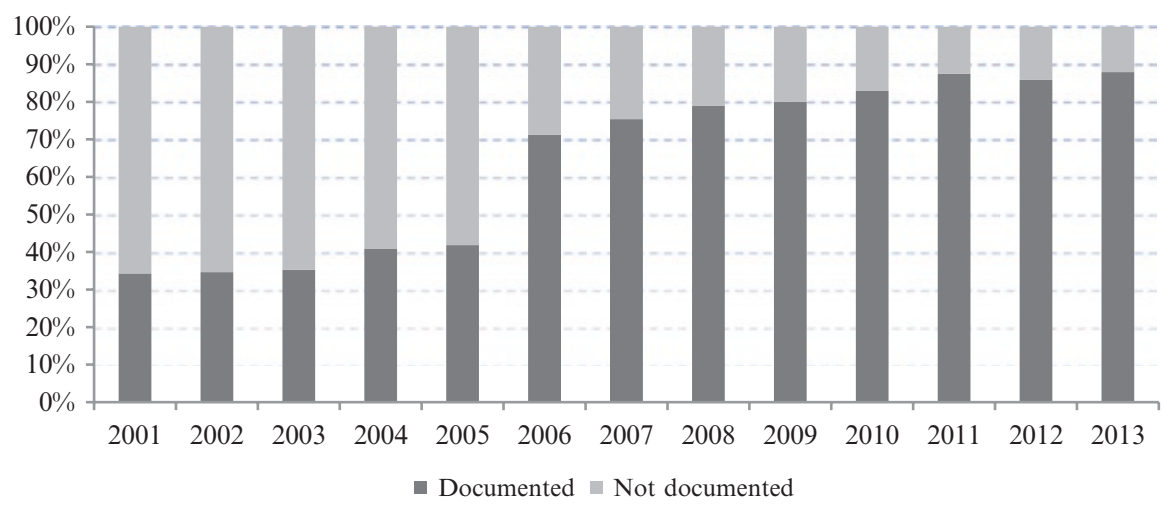

Fig. 12.8 Regularity rates for Ukrainian immigrants in Spain, 2001-2013 (Source: Authors' own compilation based on the Municipal Register (National Institute of Statistics) and the Ministry of Employment and Immigration statistics (Spain))

\subsubsection{Irregularity Rates}

Although there is no accurate statistical evidence, ethnographic research suggests that in the initial period of Ukrainian migration to Spain the majority of migrants entered the country on a short-term Schengen visa and after a brief period of regular stay became "overstayers" (Sánchez-Montijano and López-Catalán 2012; Hosnedlová 2014). This has led to a considerable increase in the number of undocumented Ukrainians residing in Spain. As shown in Fig. 12.8, between 2001 and 2005 around two out of every three Ukrainian migrants were undocumented. The implementation of extraordinary regularization in 2005 reduced the percentage of undocumented Ukrainian migrants from $62 \%$ to $29 \%$, and this share showed a further decrease to $11 \%$ in 2013 . The new legal measures enabled undocumented migrants to regularize their legal status under specific conditions via "labour" or "social" settlement schemes after 2 or 3 years of residence in Spain (see Sabater and Domingo 2012). These measures coincided with the intensification of family migration through reunification schemes. The importance of this method of obtaining residence permits among Ukrainian migrants is confirmed by the fact that by 2007 , despite its comparatively small population size, Ukrainians in Spain were among the top ten countries when it came to obtaining a residence permit by means of family regrouping (Rosario and Manzano Sánchez 2007). Finally, an important factor contributing to the significant reduction of the levels of irregularity was the slowdown of Ukrainian immigration flows as a consequence of the economic crisis (Hosnedlová and Stanek 2014). For more information on irregularity of Ukrainian migrants and the role of regularization schemes, see Chap. 4.

In Spanish literature estimated irregularity rates have been provided by Hosnedlová and Stanek (2010a, b). These authors applied the most widely used method of estimating irregularity rates: contrasting the number of foreigners registered in the municipal registers with the number of holders of valid residence permits (see Cebolla and González-Ferrer 2008). The resultant figure is adjusted by 
subtracting the number of foreign student permits, asylum seekers, and an estimate for residence permits in the process of renewal. While this method has been already implemented in a number of studies it is not free from bias resulting from inaccuracies in the municipal register (see above).

\subsubsection{Labour Market Situation of Ukrainian Immigrants}

The socio-economic situation of Ukrainian immigrants is closely linked to the fortunes of the Spanish labour market, which shows a marked sensitivity to changes in the rate of economic growth, creating a plethora of jobs in periods of expansion and dispensing with many of them when the economy shrinks. In addition to this structural feature, in the pre-crisis period a significant share of labour demand was generated by labour-intensive sectors (such as construction, hotels and catering, agriculture and domestic service) which resulted in a considerable demand for a low-skilled labour force and intense concentration of the foreign labour force in specific ethnic niches (Cachón Rodríguez 2009; Stanek and Veira 2013). Prior to 2008, Ukrainian migrants were concentrated in construction (men) and domestic services (women). According to NIS-2007, one in every two Ukrainians with a job worked in one of these two sectors. Other sectors employing a large proportion of them were agriculture (10\% of total Ukrainian population), industry (9\%) and hospitality (8\%) (Hosnedlová and Stanek 2010a; Sánchez Urios 2010). Gender differences were also apparent: men predominated in agriculture and industry; and women in retail and hotels and catering. Some geographical areas offered a greater range of jobs than others (Hosnedlová 2014). Based on information from NIS-2007, just before the outbreak of the economic crisis, Madrid region clearly had the greatest homogeneity in terms of Ukrainians' occupations, with $93 \%$ being concentrated in two major sectors, construction and services. Valencia, on the other hand, stood out as the region with the most diverse employment for the Ukrainian population, the greatest proportion of Ukrainians being engaged in agriculture $(30 \%)$ and retail $(15 \%)$. A quite different picture emerges in Barcelona where the female population had found employment linked mainly to the industry sector (26\%), while the male population was concentrated mainly in the construction sector (53\%).

The onset of the economic crisis affected certain industries in particular: construction, for example, which had previously been booming, has contracted sharply over the course of the recession. As a result, whereas it was the Ukrainian female who was more likely to be jobless before the emergence of the economic crisis in Spain, since 2008 it is the male population that has been exposed to greater risks of unemployment (Hosnedlová and Stanek 2014).Studies by Sánchez-Montijano and López-Catalán (2012) and Kuzio (2012) make some reference to the effects of Spain's economic crisis on the labour situation of Ukrainians, but focusing on the case of Catalonia. While the first cited study presents the data provided by Employment Service of Catalonia and analyzes interviews with various experts, the latter draws on a survey of a non-representative sample of 100 Ukrainians conducted in 2011. Both studies confirm a sharp decrease in Ukrainian migrants employed in the construction sector. However, it is difficult to pinpoint the precise 
impact of the crisis on this sector as the numbers diverge significantly (24\% vs. $13 \%$ ) due to the different methodological approach.

The 2011 population census contains valuable information on employment and shows that activity rates among Ukrainian migrants differed slightly between men and women. While $30 \%$ of Ukrainian men were employed in full-time jobs, it was only the case for $26 \%$ of Ukrainian women. Although women were more likely to be employed part time (14\% versus $6 \%$ of men), they were less affected by unemployment $(25.8 \%$ versus $28.4 \%)$. It is also remarkable that the percentage of students is higher among men (22.5\%) than women (18.3\%). In general terms, it may be that in times of economic crisis study is more often chosen by men as a strategy to address precariousness and unemployment. The proportion of self-employment is higher among Ukrainian men (7.8\%, mainly in construction) than women (5.7\%).

\subsection{Research on Social and Cultural Integration of Ukrainians}

The objective of this section is to present the main findings of Spanish research on the social and cultural integration of Ukrainian migrants in Spain - the focus of increasing interest in the early 2000s - and to discuss the conceptual tools and empirical data employed in the analysis of these phenomena. The first authors dealing with this thematic field were Zlobina et al. (2004), who focused on culture shock. Their main aim was to understand the difficulties that immigrants encounter in their adaptation to a new environment through the analysis of the concept of culture and its various dimensions. The analyses are quite elaborate and data come from a fairly extensive survey at national level (478 immigrants of six nationalities were interviewed and 27 immigrants took part in a focus group). Ukrainians represent a very small proportion, being a part of an Eastern European group of 53 Russians, Ukrainians and Belarusians, and the results are interpreted mostly for whole groups of immigrants. Through analysis of the perceived cultural distance, the authors show that for Eastern European immigrants the biggest difference lies in the indirect communication style of Spaniards, and that they feel the lack of warmer and more intimate relationships with the autochthonous population. An unexpected finding was that Eastern European immigrants felt closer culturally to Spaniards than was the case for immigrants of Latin American origin, which may translate into a smoother process of cultural integration in the destination country. Apart from its empirical results, the contribution of this study is the creation of guidelines for improving intercultural interaction (both for each group of immigrants and for the autochthonous population). Culture was shown to be quite a powerful conceptual tool to explain the resultant adaptation differences and how culture shock is experienced. However, it has to be taken into account that this survey was conducted in 2002 and that the average residence time of respondents was 3 years, so the immigrants were in the early stages of their migration project. It remains to be seen whether the same concept and the proposed set of guidelines would be appropriate for second and subsequent generations and immigrants of mixed parentage, assuming that in these cases the 
adoption of cultural norms is much more complex. In addition, the macro-structural conditions of the host country should be taken into account in future research as it could be reflected in changing cultural norms and dynamics.

Sánchez Urios $(2007,2008,2010 a)$, in a series of social intervention-oriented research, deals with the processes of social integration of Ukrainians in the region of Murcia and the social needs that arise in the course of this process. The analysis is based on 100 interviews conducted between 2005 and 2006 in the Murcia region. In her doctoral thesis, Sánchez Urios (2007) identified the issues that were hindering the socio-economic integration of Ukrainians in the region studied during the past decade. Among other things, the author pointed out how the downward labour mobility of Ukrainians in relation to the country of origin was causing many problems of adaptation in the process of integration into the destination community. She also observed that in the absence of social resources in the host community to meet the main needs(work, legal and other information), the Ukrainiansmainly looked for support among the informal networks represented, above all, by their compatriots (family and friends). It was more often women who sought out information and support among Spaniards because they had created networks through their work in the domestic sector. Interestingly, according to the Sánchez Urios data, it was women, though they had smaller networks and fewer friendship ties with Spaniards than men, who developed more efficient ties with host society ( $81.6 \%$ of females, compared to $56.9 \%$ of males had received some kind of help from Spaniards). Sánchez Urios in her studies $(2007,2008)$, apart from the concept of economic integration, incorporated the migration network theory and social capital into the theoretical framework. Although these works are very descriptive and require more thorough analysis of, for example, the dynamics of social ties, they exemplify how the migration network approach can be useful for developing intervention plans for immigrants.

Finally, the anthropologist Alvarez Veinguer $(2007,2008)$ explored the situation of female Ukrainian and Russian domestic workers in southern Andalusia (specifically in Granada) from the perspective of gender, focusing on the issue of power relationships in households. The importance of concepts such as immaterial work, care work and the transnational social field are discussed. Individual subjectivity in particular is stressed to explain how domestic workers manage everyday life. Although both articles provide very valuable insights into the theoretical aspects of the domestic work performed by women who had left children behind in Ukraine or Russia, they are theoretically oriented without offering empirical conclusions. It should also be noted that the author did not differentiate between the two groups studied.

To sum up this section, the notion of integration (social, economic and cultural) is generally treated as obvious and self-explanatory in the Spanish literature on Ukrainian migration, and its content often remains vague. A more in-depth discussion on the meaning of this concept would help to move research on this population beyond analysis that is purely descriptive and explanatory. In addition, analysis of the integration of Ukrainians in Spain rarely includes institutional and structural factors such as immigration and citizenship policies or the nature of the Spanish welfare regime. 


\subsection{Research on Patterns of International Mobility and Transnational Behaviour}

Other topics that are becoming central to an increasing number of studies dedicated to Ukrainian migration in Spain are patterns of international mobility and of transnational behaviour.

\subsubsection{Patterns of International Mobility}

To date the most complete and in-depth analysis of patterns of international mobility has been offered by Hosnedlová (2014). In her multidisciplinary and multimethodological research, she focused on the formation of residential intentions and decision making in the field of return migration. Most of the analysis is based on data collected between 2008 and 2012, including the results from 20 in-depth interviews and from a two-stage semi-structured interview and ego-network questionnaire with 55 immigrants in 2009, completed by longitudinal follow-up interviews conducted in 2012. Additional fieldwork was conducted in six different regions in Ukraine in 2010, where 14 returnees and some family members were interviewed.

Drawing on the social network analysis approach, Hosnedlová emphasizes the meso-level perspective and life-course approach, in which the main concept is embeddedness and its different dimensions. More specifically, the study explored the extent to which the relational environment as a whole shaped return intentions and estimated the impact on the decision-making process of different types of social networks ("concentrated", oriented to the host country; "semi-concentrated", oriented to the country of origin; "semi-dispersed", oriented to the host; and "sparse", with affective load in the country of origin). The study demonstrated that the reduction of connections in Ukraine and shift towards networks based in Spain had a positive impact on intentions to stay in the host country. Although it proved essential, the degree of relational embeddedness in Ukraine and in Spain never operated uniquely, but rather in relation to other factors such as structure of networks, subjective appreciation of personal relations in Spain and Ukraine, time of residence, labour situation, time of life and documentary situation. The research also demonstrated that while the economic crisis was not a trigger for mass return migration of Ukrainians, differences in economic and social resources as well as the psychological support provided by networks have an impact on return decisions.

This theoretically rigorous study, based on sound methodology, contributes to a better understanding of the causal mechanism behind return decision making. However, it should be borne in mind that this research was conducted with a small sample of Ukrainians in Madrid municipality, and therefore its results can hardly be extrapolated to the whole Ukrainian population in Spain. In this case the external validity of results is limited to the specific social and economic context of urban areas. The relatively small sample size hampered further exploration of the gender dimension of return; little attention has been paid to the gendered division of the 
decision-making power within households. In this regard, this study focused on individual intentions, decisions and actions, ignoring the collective dimension of return migration processes. Finally, although Hosnedlová's study sheds light on mechanisms which shape the process of Ukrainian migrants' return, it does not deal with other dimensions of international mobility, such as decision making regarding emigration and temporal mobility.

Cross-border circular migration has been covered by Marcu (2014) who focused on Eastern European migrants (Bulgarians, Moldovans, Romanians and Ukrainians) and their mobility between their countries of origin and Spain over the last 20 years. Writing from the movers' own perspective, this author examines how migrants construct their experience of mobility beyond the border. The analysis was carried out on data collected in an 8-month period between 2010 and 2011 in Spain (78 qualitative interviews in the Madrid and Valencia regions), and in the countries of origin with returned migrants from Spain (20 in-depth interviews in Romania, Moldova and Ukraine). One of the greatest contributions of the author is the comparison of the mobility practices of migrants who arrived in Spain at three different points in time: before and after the opening of the Schengen border, and following the entry of Romania and Bulgaria into the EU. The core concepts handled in this article are "learning mobility", "networked border" and "bordering". The author shows that we should not think of the border as a hindrance to human mobility, but rather as a valuable tool for learning mobility. Among other things, it has been shown that when migrants cross borders they adapt continuously to changes in European policies. This extensive research offers a very interesting insight into the patterns of international mobility; however, it focuses on the movers and returnees, omitting the category of non-migrants. Among the non-migrants will also be those who have failed in their attempts to migrate; analysis of the experience and conditions of these people could throw even more light on the mechanism of cross-border mobility.

Finally, Hosnedlová and Stanek (2010a, b) analyzed patterns of mobility from the perspective of family strategies. From their studies it is evident that one of the major consequences of migration is the break-up of the family unit both abroad and in the country of origin. Among Ukrainian migrants in Spain, at the time of the survey (NIS-2007) the total number of non-multi-local families (those in which all members of the immediate family were residing in Spain) exceeded the number of multi-local ones (those in which at least one member of the immediate family was outside Spain). In general terms, irregular immigrants were more likely to form part of a multi-local family. This pattern indicates that obtaining a permit was a crucial factor in the process of family reunification. In this sense, restrictions on obtaining legal status had a direct impact on the creation of the transnational family model.

The authors also showed that the existence of multi-local family bonds was more frequent among male immigrants. The proportion of males whose spouses and offspring were all living in Spain was almost half that of females who form part of this category. This indicates that the "male breadwinner" migration model predominated when households were making decisions on migration. Another typical migratory pattern of the Ukrainian population in the pre-crisis period was that almost a third of male migrants in Spain $(30 \%)$ had no family responsibilities, as opposed to 
$11.3 \%$ in the case of the female migrant population (NIS-2007). This might indicate that for many Ukrainian males, emigration was part of a survival strategy or an attempt to improve their individual economic situation. The proportion of women in this situation was lower, confirming that for most females the migratory decision was conditioned by the mobility of their spouse or partner. This is also supported by evidence that $38.3 \%$ of women, compared with $5.2 \%$ of men, had their spouses or partners in Spain at the time of arrival. Within this context, single-parent families (without a spouse but with children) represent a special case. Almost 22\% of the Ukrainian women in Spain found themselves in this situation, as opposed to 8.4\% of the male Ukrainians. This gender difference is principally due to the fact that when couples split up, it is usually the women who look after the children. It should be noted that due to the economic crisis the labour market in Spain has become significantly less favourable for immigrant men than women. A change in the geographical distribution of Ukrainian families is to be expected, and this could have produced a change from the Ukrainian male breadwinner model in Spain.

\subsubsection{Transnational Behaviour}

Recent articles (Stanek and Hosnedlová 2012; Hosnedlová and Stanek 2014) have examined the issues around the migratory movements of Ukrainians from a transnational perspective. The authors have provided the first empirically and statistically grounded evidence of factors determining a number of the transnational practices of Ukrainians in Spain. Three indicators of transnational practices (frequency of contact with the communities of origin, travelling to the localities of origin and remittances) have been analyzed by gender, legal status in Spain and geographical dispersion of family to determine how these factors affect the frequency and extent of transnational activities. Most of the analysis is based on NIS-2007.

Telephone calls are the most widely used means of maintaining transnational contact with migrants' communities in their country of origin. Approximately 68\% of Ukrainians said that they were in contact with close acquaintances in their home country at least once a week. Visits to the country of origin, on the other hand, are both short and infrequent. Less than a tenth of the surveyed population visited Ukraine at least once a year. In the gender category, no significant differences between males and females were observed in this regard. Finally, there was a direct relationship between the type of family and the number of visits to Ukraine. Members of multi-local families were visiting their places of origin more frequently than immigrants whose entire immediate family resides in Spain. In relation to nondirect contacts, Ukrainian immigrants maintained relationships with their communities of origin even after settling in Spain. Compared to women, men were only slightly less prone to maintain contact with their family and community of origin. With regard to economic transfers, before the crisis men were sending remittances more frequently than women. The NIS-2007 data also indicate that men remitted 
more money, the annual averages for the year 2006 being around 2,200 euros for men and 1,670 euros for women. This fact could be directly related to the persistence of the male breadwinner model among a large percentage of Ukrainian immigrant households. The geographical dispersion of the family was a very significant factor determining strategies related to remittances. More than half of the immigrants who belonged to multi-local families were sending money at least once a month. This number contrasts with that of immigrants whose entire immediate family was living in Spain. There were no significant differences between irregular and regular immigrants in the proportion of those who send money and those who do not. However, it is striking that irregular immigrants sent money to Ukraine more than twice as frequently as documented immigrants.

While Stanek and Hosnedlová's research offers the most complete work so far on transnational behaviour, it also suffers from substantial shortcomings related to data. First, the analysis is based on statistical information from the National Immigrant Survey where the variables regarding transnational activities are very limited. The operationalization of key variables related to transnational behaviour was based on proxy measures, which has a considerable impact on the empirical and conceptual reliability of particular conclusions inferred from their analyses. Second, the interpretation of results focuses mainly on family dynamics and individual decisions, and does not take into account other hypothetical structural factors such as labour market policies, legal framework or international relations at state level.

\subsection{Conclusions}

The assessment of available statistical data suggests that although the Spanish municipal register system provides relatively accurate and updated information on stocks and the basic demographic features of the immigrant population, there are substantial obstacles to a more detailed examination of mobility and specific characteristics of Ukrainians, such as labour market incorporation and family structure. The collection of statistical data in Spain has not been sufficiently adapted to the increased international mobility in this country. Since the publication of the National Immigrant Survey in 2007, no single data source providing specific information on particular characteristics of immigrant has been released. Furthermore, although the Spanish statistical system provides several general population surveys that are to some extent useful for exploration of the migrant population, the limited representativeness of subsamples affects the validity of results in research into relatively small collectives. Finally, although the population census provides representative and extensive data not available from other sources, its estimates are soon outdated with the rapid demographic and social transformations of immigrant populations.

Primary data regarding Ukrainian migrants collected by researchers suffers from substantial limitations with regard to representativeness and validity of results. Most studies are conducted by individual researchers on a small selection of interviewees 
or respondents (between 50 and 100) obtained by snowball sampling in specific locations. In addition, studies are hardly comparable due to different definitions or specifications of the target populations and diverse sampling methods. Qualitative studies are usually focused on specific subcategories and places, and specific locations.

Another characteristic of the research conducted so far on the Ukrainian population is its predominantly descriptive nature. Most of the publications assessed here describe the main features of this collective residing in Spain in terms of volume, and social and demographic variables, avoiding broader questions as to the causal mechanisms behind the phenomena observed. The few studies aiming at explanation focus mainly on individual or meso-social determinants. More research is needed to pinpoint explanatory mechanisms on a macro-structural level, as well as the geopolitical parameters of Ukrainian migration to Spain, the possible impacts of interregional tensions and internal political conflicts in Ukraine, and geopolitical competition between the EU and Russia over post-Soviet territory. In other words, there should be a greater effort to move beyond empirical generalizations and posit the phenomena observed in a broader theoretical context.

Several studies analyze Ukrainian immigrants in conjunction with other groups from Central and Eastern Europe. Nevertheless, it should be highlighted that despite their shared history of socialism installed after the Second World War that marked their socio-economic structure and organization, there are still differences between these societies that should not be overlooked. The socio-economic and political contexts of each country were already distinct before the war and they have followed very different paths since the raising of the Iron Curtain. Ukraine still does not belong to the European Union, and evinces greater political and economic instability than other post-Soviet states. In this regard, the particular macro-structural configuration of Ukraine as a sending country implies different migration conditions from those of other states of Central and Eastern Europe, so Ukrainian nationals can be expected to demonstrate unique behaviours and socio-demographic features.

This chapter's critical review of literature on Ukrainians in Spain has identified several concepts that should be tackled by future research dedicated to this collective. First, greater attention should be paid to the notion of integration and its operationalization. There is a need for longitudinal studies on integration. So far researchers have focused primarily on the early stages of the migration project of Ukrainians, but additionally, a conceptualization of circular migration is needed (see also Chap. 7). Currently it is assumed that Ukrainian migration to Spain is a long-term migration, and other possible patterns are ignored (such as ' $v a$ et vient', temporal migration and re-emigration to other EU countries). More dynamic concepts and longitudinal approaches are needed to acquire a better understanding of the complexity of international mobility. A wide range of subject areas for future research remain. Research so far has concentrated on the adult working-age population, and more attention should be paid to migrant children, second-generation Ukrainians and older people who form a significant proportion of the Ukrainian population in Spain. There are also still important research areas to be studied on 
Ukrainian family migration. Available research shows that in the last few years the number of Ukrainian migrants who have reunited their family has increased considerably. Of interest is how this phenomenon has transformed the Ukrainian population in Spain from a socio-demographic point of view, and their patterns of social and economic integration. Studies that compare migrants with non-migrants who stayed in Ukraine but are important agents in migration processes would contribute to the assessment and explanation of migration decisions by actors.

Finally, further research is needed on social interactions between Ukrainian migrants and other migrant groups or the Spanish population generally, in order to avoid the persistent analysis of migrants as a group independent of the receiving society. In that sense, as Sánchez-Montijano and López-Catalán (2012) have pointed out, as migrants are now residing in Spain for longer periods, debates related to the recognition of their political rights and socio-political participation are increasingly important. Further research could eventually focus on the impact of the current conflict between Ukraine and Russia on the international mobility of Ukrainians. There is evidence that the conflict in Ukraine has provoked an increase in flows of forced migrants to several EU countries as well as to the Russian Federation. A political mobilization of the Ukrainian diaspora has also been observed in many countries. In this complex situation, researchers are facing new challenges. Does the current conflict have any impact on Ukrainian migration flows to Spain? What strategies are new migrants using to enter the country and become integrated into the Spanish labour market? What is the role of social networks and previous migratory experience in this process? On the other hand, has the war in Southeastern Ukraine mobilized residents of Ukrainian origin in Spain? Can Ukrainian residents in Spain be observed returning and willing to participate in the conflict? These and many other questions should be addressed in current research on Ukrainian migration in the Spanish context.

\section{References}

Alvarez Veinguer, A. (2007). El universo sexuado: cuerpos invisibles pero imprescindibles. Una aproximación a experiencias de mujeres de la Europa del Este que realizan trabajos domésticos [The sexed universe: Invisible but essential bodies. An approach to Eastern Europe women's experiences in domestic service]. In A. M. Muñoz Muñoz, C. Gregorio Gil \& A. Sánchez Espinosa (Eds.), Cuerpos de mujeres: miradas, representaciones e identidades (pp. 245-63). Granada: Universidad de Granada.

Alvarez Veinguer, A. (2008). Habitando la frontera: empleadas domésticas procedentes de Rusia y Ucrania [Inhabiting the border: domestic workers from Russia and Ukraine]. In S. Castillo \& M.-J. Devillard (Eds.), Tiempo de espera en las fronteras del mercado laboral: nuevos agentes sociales en el espacio social (pp. 33-48). San Sebastian: Ankulegi Antropologia Elkartea.

Arango, J. (2004). La población inmigrada en España [The immigrant population in Spain]. Economistas, 99, 6-14.

Cachón Rodríguez, L. (2009). La 'España inmigrante': Marco discriminatorio, mercado de trabajo y políticas de integración [The "immigrant Spain": Discriminatory framework, labour market and integration policies]. Barcelona: Anthropos Editorial. 
Cebolla, H., \& González-Ferrer, A. (2008). La inmigración en España (2000-2007). De la gestión a la integración de los inmigrantes [Immigration in Spain (2000-2007). From the management of flows to integration of immigrants]. Madrid: Centro de Estudios Politicos y Constitucionales.

Duque, I., Ballano, C., \& Perez, C. (2014). The 2007 Spanish National Immigrant Survey (ENI): Sampling from the Padron. In J. Font \& M. Méndez (Eds.), Surveying ethnic minorities and immigrant populations. Methodological challenges and research strategies (pp. 69-83). Amsterdam: Amsterdam University Press, IMISCOE Research Series.

Ferrero Turrión, R. (2005). Nuevos socios, nuevas fronteras. Los procesos migratorios desde Europa Central y Oriental [New members, new frontiers. The migration processes from Central and Eastern Europe]. Barcelona: CIDOB edicions.

Fonseca, M. L., Pereira, S., \& Esteves, A. (2014). Migration of Ukrainian nationals to Portugal: Changing flows and the critical role of social networks. Central and Eastern European Migration Review, 3, 115-30.

González-Ferrer, A. (2009). National data collection systems and practices: Spanish country report. PROMINSTAT Country Reports. http://www.prominstat.eu/drupal/?q=system/files/ PROMINSTAT_Spain.pdf

Hellerman, Ch., \& Stanek, M. (2006). Nuevas perspectivas en los estudios sobre la inmigración de Europa Central y Oriental en España y Portugal [New perspectives in studies on immigration from Central and Eastern Europe in Spain and Portugal]. Papeles del Este: Transiciones poscomunistas, 11, 1-20.

Hosnedlová, R. (2014). Bridging the intention-realization gap in the process of returning. The role of networks in the experience of Ukrainians in Madrid. Doctoral thesis, Universidad Complutense de Madrid and Centro Superior de Investigaciones Scientíficas, Madrid, Spain.

Hosnedlová, R., \& Stanek, M. (2010a). Inmigrantes ucranianos en España. Una aproximación a las pautas de movilidad internacional [International mobility patterns of the Ukrainian immigrants in Spain]. Scripta Nova. Revista Electrónica de Geografía y Ciencias Sociales XIV.

Hosnedlová, R., \& Stanek, M. (2010b). Ukrainian migration to Spain: Sociodemographic profile, mobility patterns and migratory projects. In M. Baganha, J. Marques \& P. Góis (Eds.), Imigração ucraniana em Portugal e no sul da Europa: a emergência de uma ou várias comunidades. Lisboa: Alto Comissariado para a Imigração e Diálogo Intercultural.

Hosnedlová, R., \& Stanek, M. (2014). Analysing selected transnational activities among Ukrainian immigrants in Spain. Central and Eastern European Migration Review, 3(1), 99-114.

Kuzio, M. (2012). Modern Ukrainian immigration to Spain. In Europe Without Barriers (Ed.), Ukraine-Spain migration nexus. Ukraine's input to migration map of Europe on the example of Spain (pp. 37-64). Kiev: Europe Without Barriers.

Larramona, G. (2013). Out-migration of immigrants in Spain. Population (English Edition), 68(2), 213-235. doi:10.3917/pope.1302.0213.

Marcu, S. (2007). Dinámica y estructura migratoria laboral de rumanos: 1990-2006. Flujos de emigración hacia España, destino Madrid [Labour migration dynamics and structure of Romanians: 1990-2006. Emigration flows to Spain, to destination Madrid]. Migraciones, 21. 115-57.

Marcu, S. (2014). Learning mobility challenging borders: Cross-border experiences of Eastern European Immigrants in Spain. Mobilities. doi: 10.1080/17450101.2014.934055

Nikolova, M. (2015). Ukrainian migration to Greece: Patterns and challenges of remaining and of return. Central and Eastern European Migration Review, 14.

Parella, S., \& Petroff, A. (2014). Migración de retorno en España: salidas de inmigrantes y programas de retorno en un contexto de crisis [Return migration in Spain: Exits of migrants and voluntary return schemes in the economic crisis context]. In J. Arango, D. Moya Malapeira, \& J. Oliver Alonso (Eds.), Anuario de la inmigración en España (edición 2014): Inmigración y emigración: mitos y realidades (pp. 62-88). Barcelona: CIDOB.

Reher, D., \& Requena, M. (2009). The national immigrant survey of Spain: A new data source for migration studies in Europe. Demographic Research, 20(12), 253-78. doi:10.4054/ DemRes.2009.20.12.

Ródenas-Calatayud, C., \& Martí Sempere, M. (2009). Estimating false migrations in Spain. Population (English Edition), 64(2), 361-76. doi:10.3917/pope.902.0361. 
Rosario del, H., \& Manzano, L. (2007). El proceso de reagrupación familiar en la ciudad de Madrid [Process of family reunification in the municipality of Madrid]. Madrid: Observatorio de las Migraciones y de la Convivencia Intercultural de la Ciudad de Madrid.

Rosero-Bixby, L., Castro-Martín, T., Reher, D., \& Sánchez-Domínguez, M. (2011). Estimating the number of immigrants in Spain: An indirect method based on births and fertility rates. Population (English Edition), 66(3-4), 543-60. doi:10.2307/41488613.

Sabater, A., \& Domingo, A. (2012). A new immigration regularisation policy: Labour and social attachment in Spain. International Migration Review, 46(1), 191-220. doi:10.1111/j.1747-7379.2012.00884.x.

Sánchez-Montijano, E., \& López-Catalán, O. (2012). Ukrainian migrants in Spain: Overview, perception and institutional participation. In Europe Without Barriers (Ed.), Ukraine-Spain migration nexus. Ukraine's input to migration map of Europe on the example of Spain (pp. 7-34). Kiev, Ukraine: Europe Without Barriers.

Sánchez Urios, A. (2007). Inmigración, necesidades y acceso a los recursos y servicios: los inmigrantes ucranianos en los procesos de inserción en la Comunidad Autónoma de Murcia [Immigration, needs and access to resources and services: Ukrainians in the integration processes in the region of Murcia]. Doctoral thesis, Universidad de Murcia, Murcia.

Sánchez Urios, A. (2008). Los ucranianos residentes en España en los procesos de inserción/integración: necesidades, diferentes fases de proyecto migratorio [The Ukrainians living in Spain in the processes of insertion/integration: Needs, different stages of migration project]. Migraciones, 24, 135-162.

Sánchez Urios, A. (2010). Las redes migratorias y la intervención social: un estudio de caso de la comunidad ucraniana en la región de Murcia [Migration networks and social intervention: a case of the Ukrainian community in the region of Murcia]. Cuadernos de trabajo social, 23, 65-84.

Stanek, M. (2009). Patterns of Romanian and Bulgarian migration to Spain. Europe-Asia Studies, 61(9), 1627-1644.

Stanek, M., \& Hosnedlová, R. (2012). Exploring transnational practices of Ukrainian immigrants in Spain. Economics \& Sociology, 5(1), 62-73.

Stanek, M., \& Veira, A. (2013). Occupational nobility at migration: Evidence from Spain. Sociological Research Online, 18 (4). doi: 10.5153/sro.3134

Vianello, F. A. (2014). Ukrainian migrant workers in Italy: Coping with and reacting to downward mobility. Central and Eastern European Migration Review, 3, 85-98.

Viruela Martínez, R. (2002). La nueva corriente inmigratoria de Europa del Este [The new wave of immigration from Eastern Europe]. Cuadernos de geografía, 72, 231-258.

Zlobina, A., Nekane B., \& Páez D. (2004). Adaptación de los inmigrantes extranjeros en España: superando el choque cultural [The adaptation of foreign immigrants in Spain: Overcoming cultural shock]. Migraciones, 15, 43-84.

Open Access This chapter is distributed under the terms of the Creative Commons AttributionNoncommercial 2.5 License (http://creativecommons.org/licenses/by-nc/2.5/) which permits any noncommercial use, distribution, and reproduction in any medium, provided the original author(s) and source are credited.

The images or other third party material in this chapter are included in the work's Creative Commons license, unless indicated otherwise in the credit line; if such material is not included in the work's Creative Commons license and the respective action is not permitted by statutory regulation, users will need to obtain permission from the license holder to duplicate, adapt or reproduce the material. 